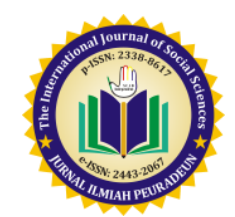

\title{
THE INFLUENCE OF LEADERSHIP IN IMPROVING PERSONNEL PERFORMANCE AT TRADITIONAL ISLAMIC BOARDING SCHOOL (DAYAH)
}

\author{
${ }^{1}$ Nasir Usman, ${ }^{2}$ Murniati AR, ${ }^{3}$ Marzuki \\ ${ }_{1,2}$ Faculty of Teacher Training and Education, Syiah Kuala University, Banda Aceh \\ ${ }^{3}$ Master of Education Administration Syiah Kuala University, Banda Aceh \\ E-mail: nasir.fkip@gmail.com
}

Received: Nov 25, 2015

Accepted: Jan 12, 2016

Published: May 28, 2016

Article Url: https://journal.scadindependent.org/index.php/jipeuradeun/article/view/98

\begin{abstract}
This study aims at determining styles of leadership in improving the performance of personnel, factors affecting the personnel performance, and inhibitors in improving the performance of personnel. This study used a qualitative approach with descriptive methods. Data collection techniques were done through observation, interview and documentation study. The subjects were principal, vice director, heads of division, and teachers of Dayah. The results showed that: 1) The leadership styles of dayah in improving the performance of personnel was a consultative, participative and instructive leadership style. 2) Factors that affected performance of personnel were the authority and charismatic of the principal in the presence of personnel, and democratic in decision making, and the religious environment, 3) The limiting factors in improving the performance of the personnel were the number of students that exceeds the capacity dormitories which were available, some of the personnel did not have the administration skill background, the minority of personnel who were less active, and were not able to provide financial support for the personnel.
\end{abstract}

Keywords: Traditional, Islamic Boarding School, Leadership, Personnel, Performance 


\section{A. Introduction}

The process of developing spiritual strength in order to become a perfect human being has been more visible in Islamic educational institutions, one of which is the Traditional Islamic boarding school (Dayah). Regarding the education system of dayah, Abu Bakar (2011: 23) argued that from the beginning until now, dayah still adopt the traditional pattern. In general, education in dayah does not use the existing curriculum as in public schools.

The objective of education of Dayah is to make Muslims to have an Islamic personality. Accordingly, Rizal (2011: 45) explained that "Dayah aims at nurturing and educating Muslims in order to have an Islamic personality, thinking and acting skill". Thus the objective of dayah is equal to national education goals which aim at delivering students to have good personalities and skills.

One of Islamic educational institutions in Aceh is Dayah. As explained by Amiruddin (2009: 62), Dayah is an educational institution that has been born since Islam arrived in Aceh. In the Sultanate era in Aceh, the only institution that had been instrumental in educating the nation was dayah.

The statement that was hinted by Amiruddin above shows that dayah is a very meritorious institution in order to educate the people of Indonesia. Since the time of the sultanate of Aceh, dayah as educational institution has given contribution in educating generations of the nation before the public education institutions were established to our homeland so that educational institutions of dayah is called the oldest educational institution in Aceh and in Indonesia.

Each activity in educational institution of dayah is not separated from the leadership styles of a principal and morale of personnel, because the leadership is the activity affecting the activity of another person toward a goal that has been set together. This is in line with the explanation of Rivai \& Murni (2009: 285) that "leadership is an activity to influence the behavior of people to work together toward a particular goal they want". 
Dayah Ma'hadal Ulum Diniyah Islamiyah of Mesjid Raya (MUDI Mesra $)^{1}$ Samalanga, Bireuen is a dayah which has long been acting to promote Islamic education in Aceh. This institution has been established since the time of Iskandar Muda located in the village of Miden Jok of Samalanga, Bireuen, the vision is to create scholars and intellectuals that are based on the five souls who become ruhul ma'had (dayah souls), that is, sincerity, simplicity, self-sufficient, ukhwah Islamiyah (Muslim brotherhood) and freedom.

Based on that vision above, Islamic boarding school MUDI Mesra of Samalanga, Bireuen has been immersed by norms of Islamiyah doctrine, where Islam tenet emphasizes subservience and tawadhu' (humility) of students to their teachers.

The description of behavior of students above is expected by all parties, both government and society. To create such atmosphere, it needs hard work, especially from the dayah management and achieved through the dedication and sense of belonging to the dayah, moreover the on-going system of Islamic boarding school MUDI Mesra of Samalanga, Bireuen. The dayah has built a culture of work that does not expect a salary.

After seeing this phenomenon, it shows that the increasing personnel performance cannot be separated from the leadership styles adopted by the leaders and its implications on the performance of teachers and administrators to build the spirit of their service as supports in any activities performed. Nevertheless, there are also personnel that look lackluster on their works, so, an evaluation meeting on the performance of subordinates by vice principal and head of the division should be held. Based on the problems above, the author was interested in doing research on how leadership styles improving performance of personnel at MUDI Mesra of Samalanga, Bireuen.

\section{B. Method}

The approach used in this study is a qualitative approach by using descriptive method. This study was done at Islamic boarding school MUDI Mesra

\footnotetext{
${ }^{1}$ Hereinafter referred to MUDI Mesra
} 
of Samalanga, Bireuen. The research had been conducted for 3 (three) months. In accordance with the focus on leadership of dayah in improving the performance of personnel, the data sources or subjects in this study include: (1) dayah principal; (2) the Vice Director (vice-principal) of dayah; (3) the heads of the division (head section) in the management of dayah; and (4) the members or administrators in Islamic boarding school MUDI Mesra of Samalanga, Bireuen.

There are some ways of data collection techniques according Bungin (2007: 108) as follows: (1) Observation; (2) Interview; and (3) Documentation. Therefore, in this study, the data obtained will be analyzed by using a specific procedure that produces good results.

\section{Research Finding \\ 1. The style of leadership in improving the performance of personnel in MUDI Mesra of Samalanga, Bireuen.}

Based on interviews, the leadership style applied daily by the dayah the leaders are consultative and participative style of leadership. Related to the improvement of personnel performance, the leaders of dayah do the instruction through two-way communication and explanations that lead on the tasks that need to be done by personnel. The leaders constantly support personnel to do the work properly and train personnel to provide advice to the policy of the organization.

The participative style seeks the leaders and personnel to take part in decision-making, the leaders are really appreciate the effort and participation of personnel by providing simplicity and communicating several matters related to personnel, especially personnel motivation and creativity. The answer of the vice principal regarding leadership style applied daily is instructive leadership style, that is, the leaders play many roles in directing personnel assignments. The leaders formulate personnel roles and provide instructions so that leaders exert strict control in order to achieve program objectives.

\section{Factors Influence Leadership in Improving the Personnel Performance at MUDI Mesra of Samalanga, Bireuen}

From the research that was done, it was found that the supporting factors in improving the performance of personnel at Islamic boarding school MUDI 
Mesra of Samalanga, Bireuen were (1) the leaders, that is, those who lead; (2) followers, namely organizational positions; and (3) the environment, the situation in question in order to established good cooperation.

Good cooperation between one part and the other is also the most preferred supporting factor in carrying a huge task. Any suggestions submitted by the leaders were received and done well as expected. Cultural obedience to superiors is one of the factors that facilitate the personnel in the work so that each personnel contribute in work part. In addition, the number of personnel is sufficient, even though, there were few personals that were not active, but it does not affect anything in the duty. Mutual coordination among subordinates, the leaders, and other subordinates fellows was the most support for doing activities at dayah. This is shown through the spirit of good work by subordinates, Vice Director, head of the section or section members, including teachers in charge of teaching who were mutually respect of each other.

Other supporting factors from the leader party are: they are easy to meet, they receive suggestions and constructive ideas from their subordinates, and they provide opportunities for the personnel to develop themselves by improving their knowledge and skills. In addition, the support of communities for the dayah is quite good.

\section{Obstacles Faced by the Leader of Dayah in Improving the Performance of Personnel in MUDI Mesra of Samalanga, Bireuen Regency}

Obstacles faced by the leaders of the dayah in improving the performance of the personnel in MUDI Mesra of Samalanga, Bireuen is mainly in forming of cadres in term of giving them opportunity to be involved in the management of dayah. Actually, there is no significant problem, but there are some personnel who are not proactive to be involved as members of certain divisions, they prefer to choose the division they want to involve in based on they own preference.

Obstacle encountered in administration is there are some personnel in charge for the dayah administration do not have adequate background in administration field. To solve this problem, the leaders of dayah has provided a solution by inviting experts in administration field to give management 
training to the personnel of the dayah. Not all personnel in dayah have adequate background in leadership skill. However, the learning process and other activities in dayah are not constrained. The constraints and problems faced by the personnel will increase their knowledge and experience in accordance with the need to overcome the existing problems to find ways to cope with the existing shortages. It means that to run leadership activities of dayah do not have to be expert in leadership.

The institutions cannot afford to give allowance to the personnel, so that some of the personnel have a side-job outside the dayah to finance their life. Consequently, their main job in the dayah is not covered well. Next, unlimited admission of students has exceeded the capacity of available dorm. The exceeded number of the students results in insufficient dormitory rooms to be occupied. Consequently, room capacity of eight people is occupied by twelve students. In order to resolve the problem, the leaders of the dayah try to extend the student dormitory to meet increasingly urgent needs.

\section{Discussion}

In order to improve the performance of personnel, leadership styles are crucial in guiding, directing, and providing guidance to personnel. The leadership style in educational units is an effort to understand the needs and willingness of dayah personnel, primarily related to the needs of the personnel that is assist in order to improve their insight and knowledge. It is in accordance with the opinion of Rivai, et.al (2009: 288), "leadership styles are different from the types of leadership, leadership styles are inclined to the situation, in other word, a type of leadership can be adapted to different styles of leadership". The style of the leader depends on the psychology lens of the leader. The studies show that an increasing numbers of voices are challenging leadership psychology's emphasis a strong inner motor of leader traits, cognition, and styles (Fairhust, et.al, 2014).

Second, Participative style, this leadership style promotes the cooperation between the leaders and the personnel of the dayah to work together in making decisions. The Leaders of dayah highly appreciate the efforts of personnel by providing convenience and communicating some 
matters relating to the personnel, especially about personnel motivation and creativity. Several studies by researchers had found that leadership style affected organization from different perspective such as employee's attitudes and behaviors, which might also, affected the feelings and thoughts of employees (Cetin, et.al., 2012).

Third, Instructive leadership style, this leadership style focus mainly on the role of the leaders in directing personnel assignments. The leaders formulate the roles of the personnel and give instructions to the personnel. The leaders exert strict control in order to achieve leadership objectives. The studies showed that an effective organization usually lead by an effective leader (Horng \&Loeb, 2010). Using leadership styles is a way used by the leaders of dayah in improving the performance of personnel. There is no one ideal style, they must be adjusted to the level of the willingness and ability of the personnel. However, to establish the professionalism of the personnel, in selecting a leadership style a leader needs to consider several things, a leader should: (1) be able to accurately see the problems or needs for improvements, (2) have a dynamic and advanced educational insights and, (3) be expert in drafting and skilled in developing program, (4) have a strong commitment to influence subordinates in completing tasks, (5) be very energetic and work diligently to guide and develop personnel in order to enhance their professionalism, and (6) be able to work well in a relatively long period.

Rivai \& Mulyadi (2012: 2) stated that, "leaders of dayah should be able to influence and motivate the attitude of their personnel in achieving organizational goals, and be able to influence them in order to improve their group and culture". In its eventual, it will impact the effectiveness of their leadership. It was described by Danim \& Suparno (2012: 119-121) that "one of the effective leadership characteristics is that the leaders naturally know how to work most efficiently and effectively, because they have learned from their successes and failures in honing their skills, they integrate their experiences, skills, competencies, and consciousness into an effective and efficient performance ".

If the leaders of the dayah want to achieve the goals that have been set well, it is necessary to improve the performance of the personnel by 
providing authority and freedom as well as support in working. As for the factors that affect the improvement of the personnel performance at Dayah MUDI Mesra of Samalanga, Bireuen are: (1) the leaders, people who have authority and are charismatic in the presence of personnel as well as democratic in running their leadership; (2) the followers, namely organizational positions which are all held by the disciples of the leaders of the dayah so that the level of compliance and loyalty has been strongly etched in them respectively; and (3) environment, namely related situation in order to establish good cooperation because it is based on the existence of a strong emotional connection.

Therefore, the leadership is determined by the state of the leader and the followers in the environment where the leadership process is running. In this case, Gunawan (2012: 142) also revealed that "leadership is largely determined by the work situation or circumstances of subordinate and organizations supporting resources.

The inhibiting factor in improving personnel performance of Dayah MUDI Mesra of Samalanga, Bireuen are: there are some of the personnel who do not have background knowledge on leadership skill as the foundation in running the leadership activities, so that the efforts to develop personnel leadership skill or dayah management is needed in the process of managing the dayah. However, the learning process in dayah is not constrained. The constraints and problems faced by the personnel will increase their knowledge and experience to overcome the problems so as to find solution to cope with the existing shortages.

The next obstacle is the dayah is not able to provide allowances to the personnel. This also become an obstacle faced by the leaders because some of personnel will have a side-job outside dayah activities in order to meet the needs of their own life that would, more or less, disturb the dayah leadership process. To solve this problems, some previous researches, suggest the leader to adopt virtual model of leadership in dayah management. The result showed that the virtual leadership has contributed positively to intra-team communication, while intra-team communication positively increases the team performance, through the technology, such as mobile phone, a leader and the 
personnel can work at any place and time (Desanctic\& Poole, 1994; Avolio, et.al, 2001; Purvanova \& Bono, 2009; Ibrahim, 2015).

In connection with the above description, the leaders need to be careful and wise in facing these obstacles. Leaders should wisely take the motive as an effort to find a solution in directing personnel to a harmonious atmosphere so that personnel would not feel bored in carrying out their duties although they are in a state of all-is not supported by a wide range of needs. Wibowo (2013: 102-105) stated that, "as an effort to improve the performance of personnel in the organization, leaders can facilitate the motivation of subordinates".

There are several steps related to the above-mentioned factors inhibiting the Dayah MUDI Mesra of Samalanga, Bireuen. As proposed by Stoner (Sutrisno, 2011: 184) that there are several ways to improve the performance, namely: "(a) discrimination, it means that distinguishing subordinates who are good achievers and who are not, (b) expectation, it means that the leader should be able to see the expectation of the work done, so the awards actually are given to those who deserve it, (c) development, it means that the development for the subordinate, those who are not able to work or those who already have a standard in its work needs to be developed through promotion and so on, (d) the communication, that is the leaders need to communicate intensely with their subordinate".

In relation with the factors influencing the process of leadership, either supporting or inhibiting factors is two things that are closely related with the policies taken by the leaders. Reitz (Wahab and Umiarso, 2011:111) stated that "in this case the factors influencing the leaders of the dayah in the efforts to improve the performance of the personnel are personality, expectation and leader attitude, characteristics, expectation and subordinate attitude, duty needs, as well as organizational climate and policy".

Hence, the inhibiting and supporting factors in the leadership are two things that should get more attention from the leaders of the dayah. Supporting factors can be used as a medium to successful leadership programs. Conversely, inhibiting factors can be used as an evaluation to look for alternative solutions as a form of anticipatory situation. 


\section{E. Conclusion}

Based on the description and discussion above, it can take several conclusions, namely:

1. Leadership styles used by the dayah in improving the performance of the teachers in Dayah MUDI Mesra of Samalanga, Bireuen Regency are: (1) Consultative leadership style, which is in compliance with the ability of the personnel; (2) Participative leadership style, this leadership style emphasize on discussion in making decisions, it prioritize cooperation above others; and (3) Instructive leadership style, this leadership style focus on the role of the leaders in directing personnel tasks.

2. Influencing factors in improving the personnel performance in Dayah MUDI Mesra of Samalanga, Bireuen, among others: (1) the leaders of the dayah are wise and charismatic in the presence of the personnel; (2) The leaders show democratic attitude towards the personnel; (3) Organizational positions were held by the disciple of the leaders; and (4) The environment is conducive.

3. Inhibiting factors in improving the performance of the personnel are: the number of students exceeds the available capacity of the dayah, some of the personnel do not have the background knowledge in administration field, some personnel are less active, and there is no available financial support for personnel.

\section{Bibliography}

Abubakar, M. (2011). Pendidikan Islam di Dayah: Antara Modemisasidan Tradisi. SekolahTinggi Agama Islam (STAI) Aziziyah Samalanga Tahun2011. [Online] (6), 11 pages. http://www.academia.edu/5141037/Pendidikan Islam di Dayah Antara Modernisasi dan Tradisi (retrieved on February15, 2014).

Amiruddin, H. (2009). Menatap Masa Depan Dayah di Aceh. Yogyakarta: Polydoor.

Aviolio, B.J., Kahai, S., \& Dodge, G.E. (2001). E-Leadership: Implications for Theory, Research, and Practice. Leadership Quarterly, 11(4), 615-668.

Buseri, Kamrani. (2015). Epistemologi Islam dan Reformasi Wawasan Pendidikan. Jurnal Ilmiah Peuradeun, 3 (1), 77-102 
Cetin, M., Karabay, M.E., \& Efe, M.N. (2012). The Effects of Leadership Styles and the Communication Competency of Bank Managers on the Employee Job Satisfaction: The Case of Turkish Banks. Journal of Social and Behavioral Sciences, 58, 227-235.

Danim, S, \& Suparno. (2012). Menjadi Pemimpin Besar, Visioner Berkarakter. Bandung: Alfabeta.

Desanctis, G., \&Poole, M.S. (1994). Capturing the Comlexity in Advanced Technology Use: Adaptive Structuation Theory Organization. Science, (5), 121-147.

Fairhust, G.T., \& Connaughton, S.L. (2014). Leadership: A communicative Persepective. Leader Article SAGE, 2014, Vol 10(1) 7-35.

Faruqi, Y. M. (2015). Role of Muslim Intellectuals in the Development of Scientific Thought. Jurnal Ilmiah Peuradeun, 3(3), 451-466

Fatimatuzzahroh, Feti, Oekan S. Abdoellah, and Sunardi. (2015). The Potential of Pesantren in Sustainable Rural Development (Case Study: Pesantren Buntet in Rural Mertapada Kulon, Subdistrict Astana Japura, Regency Cirebon, Province. Jurnal Ilmiah Peuradeun, 3 (2), 257-278

Gunawan, H. (2012). Pendidikan Karakter, Konsepdan Implementasi. Bandung: Alfabeta.

Horng, E, \& Loeb, S. (2010). New Thinking about Instructional Leadership. Kappan, 92 (3), 66-69.

Ibrahim, M.Y. (2015). Model of Virtual Leadership, Intra Team Communication and Job Performance Among School Leaders in Malaysia. ProcediaSocial and Behavioral Sciences 186 (2015) 674-680.

Purvanova, R.K., \&Bono, J.E. (2009). Transformational Leadership in Context: Face to Face and Virtual Teams. The Leadership Quarterly 20 (2009) 343-357.

Rivai, V \& Murni, S. (2009). Education Management (Analisis Teoridan Praktik). Jakarta: Raja Grafindo Persada.

Rivai,V\& Mulyadi, D. (2012). Kepemimpinan dan Perilaku Organisasi. Jakarta: Raja Grafindo Persada,

Rizal, S. A. (2011). Transformasi Corak Edukasi dalam Sistem Pendidikan Pesantren, dari Pola Tradisike Pola Modem. [Online] Vol 9 (2). Available at: http://jurnal.upi.edu/file/01_Transformasi Corak Edukasi Dalam Sistem Pendidikan Pasantren dari Pola Tradisi Ke Pola ModemRizal.pdf[retrieved on June 6, 2014]

Sutrisno, E. (2011). Budaya Organisasi. Jakarta: Kencana. 
Tan, C. (2015). Educative Tradition and Islamic School in Indonesia. Jurnal Ilmiah Peuradeun, 3 (3), 441-450

Wahab, A \& Umiarso. (2011). Kepemimpinan Pendidikan dan Kecerdasan Spiritual. Jogjakarta: Ar-Ruzz Media.

Wibowo. (2013). Manajemen Kinerja. Jakarta: Raja Grafindo Persana.

ZA, T. (2014). Islamic Studies dalam Pendekatan Multidisipliner (Suatu Kajian Gradual Menuju Paradigma Global). Jurnal Ilmiah Peuradeun, 2(2), 211-234. 